\title{
Teplota sněhu při běhu na lyžích v obraze dynamické termografie (Pilotní studie)
}

\section{Snow temperature during cross-country skiing at dynamic thermography image (Pilot study)}

\author{
Jan Novotný sr., Jan Novotný
}

Fakulta sportovních studií Masarykovy univerzity

\begin{abstract}
Abstrakt
Již staršími statickými metodami bylo prokázáno, že tření lyže ohřivá sníh. Vzniklá tenká vrstva vody umožňuje skluz lyže. Cílem naší studie bylo zjistit, zda i dynamická infračervená termografie je schopna registrovat rychlé změny teploty sněhu v jednom určitém bodě před a po projetí lyže.

Monitorovali jsme sníh ve stopě po 12 jízdách rekreačního běžce na lyžích různými rychlostmi, bez i s mazáním lyží a s různým zatížením lyží. Měření infračerveného záření a výpočet teploty na povrchu sněhu bezprostředně před a po projetí lyžaře bylo provedeno termografickým systémem FLIR SC620 s vzorkovacífrekvencí $30 \mathrm{~Hz}$.

Byly zjištěno významné zvýšení teploty sněhu po projetí lyžaře (o 0,2 až $\left.1,7^{\circ} \mathrm{C}\right)$, lineární závislost zahřátí sněhu na rychlosti a zvýšení teploty po namazání lyže.

Studie potvrdila schopnost dynamické infračervené termografie citlivě registrovat velmi rychlé teplotní změny sněhu v jednom bodě bezprostředně pred a po (do 0,033 s) projetí běžce na lyžích. Otevírá se tak možnost dalšího studia rychlých termodynamických změn, které by přispělo $k$ hlubšímu pochopení zákonitostí tření a skluzu v běžeckém lyžování.
\end{abstract}

\section{Abstract}

The effect of ski friction on the snow temperature increasing is known. The made water film facilitates the ski moving. The aim of our pilot study was to ascertain a capability of the dynamic infrared thermography to register the quick thermal changes at determined point of snow before and after ski moving.

We monitored snow after immediately before and after 12 runs of recreational cross-country skier by dynamic infrared thermography FLIR SC620 with image frequency $30 \mathrm{~Hz}$.

We found significant increasing of snow temperature (by 0,2 to $\left.1,7^{\circ} \mathrm{C}\right)$, linear dependence of snow warming on ski moving speed, and temperature increasing after ski waxing.

The study confirmed the dynamic infrared thermography ability to register very quick changes at determined point of snow temperature before and after (less than 0,033 s) cross-country skier moving. We have opened next thermodynamic studies for profound understanding of cross-country ski friction and gliding on snow.

Klícová slova: $\quad$ teplota sněhu, běžecké lyžování, infračervená termografie

Key words: $\quad$ snow temperature, cross country skiing, infrared thermography

\section{ÚVOD}

Již dlouhou dobu je známo, že sníh je třením lyže ohříván a mikroskopická vrstva vzniklé vody umožňuje skluz (Bowden et Hughes 1939), podobně jako tající led pod bruslí (de Koning et al. 1992, de Koning et van Ingen Schenau 2000, Smith 2000). Odpor a teplota sněhu ve stopě patří mezi hlavní faktory, které ovlivňují statický i dynamický skluz běžecké lyže (Svensson 1994, Gnad a Psotová 2005). Dalšími důležitými prvky jsou také meteorologické podmínky, mechanické vlastnosti lyže, povrch a ošetření skluznice (Theile et al. 2009), zvláště pak v klasickém běžeckém lyžování pro docílení optimálního tření při odrazu a skluzu. 
Změny teploty sněhu lze zjištovat různými způsoby. Starší kontaktní i bezkontaktní termometrické systémy umožňovaly měření teploty sněhu až více vteřin po průjezdu lyže a výsledky měření byly nutně zkresleny zevními faktory, které po tuto relativně dlouhou dobu na sníh působí.

Infračervená termografie nachází uplatnění ve sportu častěji při diagnostice zánětlivých ložisek v souvislosti s přetížením struktur pohybového aparátu apod. (Novotný 2009). Ojedinělou práci, která se zabývá zahřátím běžícího koberce i sněhu lyží, publikoval Roberts (1991). Analogické zkušenosti s ohřevem ledu při metání koštaty v curlingu publikoval Bradley (2009). Avšak jde o snímky statické infračervené termografie. Statická termografie umožňuje pouze pohled na objekty v jednom okamžiku jako fotografie. Pokud je zaměřena na infračervené záření sněhu před a za lyží, jde o měření dvou různých bodů v lyžařské stopě. Srovnání teplot dvou bodů, které podléhají poněkud odlišným vlivům, je problematické a ne úplně správné.

Možnosti moderní dynamické infračervené termografie a článek o curlingu nás přivedly $\mathrm{k}$ myšlence zjištování vlivu lyže na teplotu sněhu skutečně bezprostředně před a po jejím projetí. V dostupných zdrojích odborných informací, včetně elektronických databází, jsme zatím nenašli publikaci, která by prezentovala podobné výsledky. Přesnější poznatky o vztahu použití mazacího vosku, rychlosti jízdy, hmotnosti jezdce, zevních klimatických podmínek atd. k nárůstu teploty sněhu by zřejmě mohly být využity pro optimalizaci přípravy lyží na trénink a závody.

\section{Cílem této jednoduché metodické pilotní studie je zjistit}

- jak se změní teplota sněhu jednoho určeného bodu ve stopě skutečně bezprostředně po průjezdu běžce na lyžích (do $0,1 \mathrm{~s}$ ),

- zda použití dynamické infračervené termografie otevře nové možnosti studie vlivu stavu a ošetření skluznice na rychlost běhu na lyžích.

\section{METODIKA}

Měření jsme provedli s 56 letým mužem s hmotností 84 kg a výškou $178 \mathrm{~cm}$, který jezdí pouze rekreačně na běžkách, asi $2 \mathrm{x}$ ročně.

Použili jsme běžecké lyže Sporten Sprint Racing RCX CAD celkové délky $198 \mathrm{~cm}$ (délka skluznice, která je v kontaktu se stopou: $195 \mathrm{~cm}$ ) a šířky černé grafitové skluznice $4,5 \mathrm{~cm}$, vázání Rottefella II-NNN a běžeckou obuv Rossignol X-3. K mazání skluznice lyže byl použit modrý vosk SWIX $0 /-3^{\circ} \mathrm{C}$.

Měření proběhlo 28.ledna 2010 v odpoledních hodinách 14,15-14,45 ve stínu. Počasí: polojasno. Výška čerstvého jemnozrnného sněhu byla $25 \mathrm{~cm}$. Stopa byla vytvořena šestinásobným projetím lyžaře. Ostatní zevní podmínky jsou uvedeny v tabulce č.1.

Tab.1: Zevní klimatické podmínky při měření.

\begin{tabular}{|c|c|c|c|}
\hline Výška nad sněhem $(\mathrm{m})$ & Teplota $\left({ }^{\circ} \mathrm{C}\right)$ & Relativní vlhkost $(\%)$ & Rychlost větru (m/s) \\
\hline 0,02 & $+0,2$ & 77,7 & 0,9 \\
\hline 2 & $+0,4$ & 80,0 & 3,3 \\
\hline
\end{tabular}

Způsoby jízdy na běžkách, při nichž byla vypočítávána teplota sněhu stopy před a po projetí lyže, byly následující:

1. bez vosku na skluznici co nejpomaleji (aby běžec ještě projel setrvačností ve stopě alespoň $3 \mathrm{~m}$ kolem kamery).

2. bez vosku na skluznici co nejrychleji.

3. s voskem na skluznici levé lyže co nejpomaleji.

4. s voskem na skluznici levé lyže co nejrychleji.

5. s voskem na skluznici obou lyží co nejpomaleji.

6. s voskem na skluznici obou lyží co nejrychleji.

Každým způsobem byla stopa projeta dvakrát. Celkem to bylo 12 jízd. Poslední odpich holemi před projetím kolem kamery byl soupaž. 
Infračervené záření bylo snímáno a výpočet teploty prováděn infračerveným termografickým videosystémem FLIR SC 620 (Obr.1): Teplotní citlivost $0,065^{\circ} \mathrm{C}$ ve $30^{\circ} \mathrm{C}$, spektrální rozsah 7,5-13 $\mu$ m, teplotní rozsah -40 až $+120^{\circ} \mathrm{C}$, přesnost stanovení teploty $\pm 2^{\circ} \mathrm{C}$, obrazové rozlišení $640 \times 480$ pixelů. Snímkovací frekvence byla 30 Hz. Pro on-line přenos sekvencí obrazů do laptopu PHILIPS bylo využito systému Wireless.

Při měření byla kamera $1,5 \mathrm{~m}$ nad úrovní běžecké stopy, mírně šikmo - s úhlem $20-30^{\circ}$ od svislice, aby kameraman nebránil průjezdu běžce. Současně bylo zaměření kamery voleno tak, aby sníh neodrážel jiné zdroje infračerveného záření, které by mohlo zásadně zkreslit výsledky, jak se o tom zmiňuje např. Honner (2004).

K následnému zpracování sekvencí snímků byl použit software ThermaCAM Researcher Professional 2.9 (Obr.2). Po zadání emisivity sněhu 0,85 a dalších nezbytných údajů, byly stanoveny statické body měření ve sněhové stpě. Byly vypočteny jejich teploty $\mathrm{v}$ intervalu do $0,033 \mathrm{~s}$ před a po projetím lyže a rozdíly mezi těmito teplotami. Rychlost pohybu lyže byla vypočtena $\mathrm{z}$ časů, za které projede celá lyže v místě bodu měření.

V programu Statistica CZ 9.0 byly vypočteny základní statistické charakteristiky polohy a rozptylu hodnot a byl proveden neparametrický Wilcoxonův test rozdílu teplot před a po projetí lyží. Pro posouzení vztahu rychlosti lyží a rozdílu teplot byl použit test lineární korelace. K výpočtům a grafickému vyjádření výsledků posloužil tabulkový procesor Excel MS Office 2003.

Obr.1: Infračervená termografická kamera FLIR SC 620

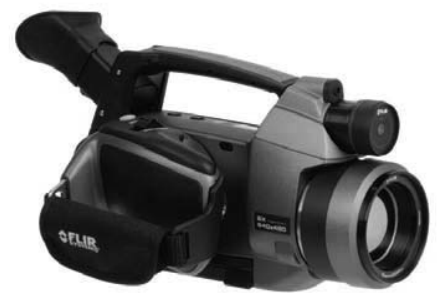

Obr.2: Pohled na monitor při analýze výsledků programem ThermaCAM Researcher Professional 2.9

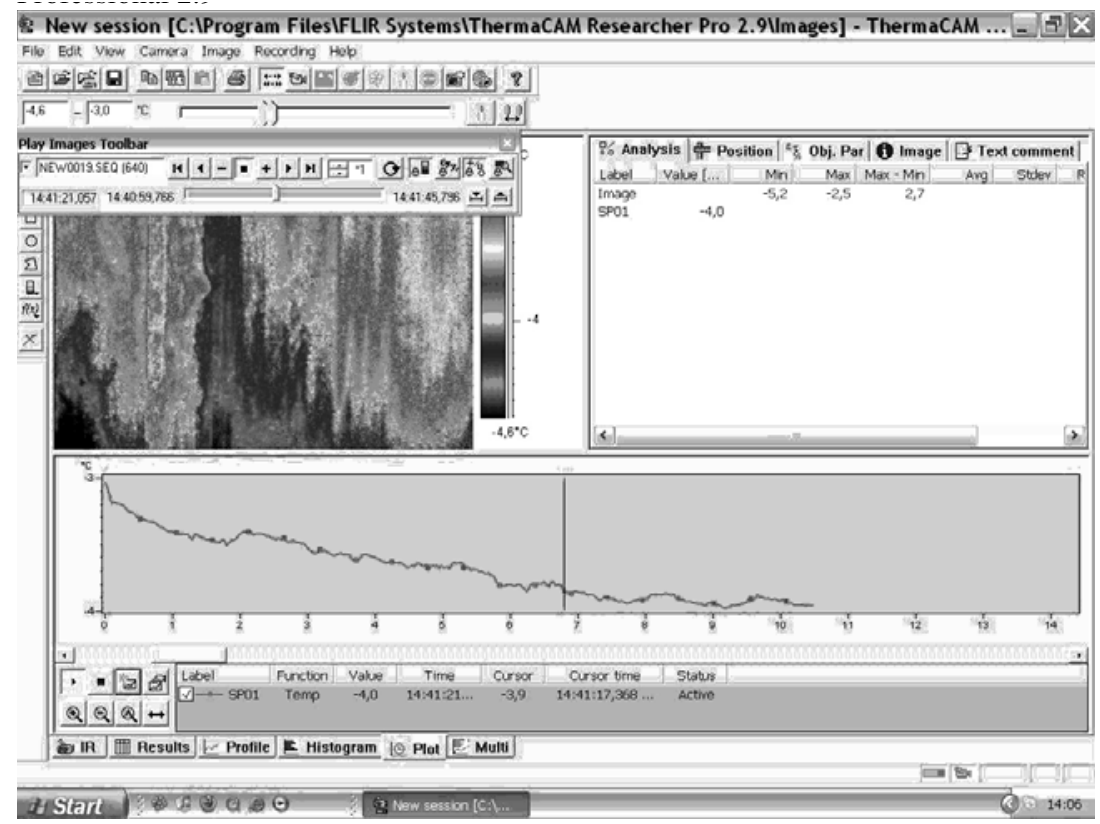

Vysvětlivky: Vlevo je výřez z termogramu. Ke stanovení měřených bodů je potřeba kontrastní barevný obraz a především porovnávání předchozích a následných obrazů $v$ sekvenci. Vpravo jsou číselné výsledky vypočtených teplot $\left({ }^{\circ} \mathrm{C}\right)$. Dole je graf snižování teploty stanoveného bodu v průběhu času (s). 


\section{VÝSLEDKY}

V tabulce č.2 uvádíme všechny vypočtené teploty sněhu bezprostředně před a po projetí lyží, rozdíly těchto teplot, rychlosti pohybu lyží a dobu, za kterou se ochladí sníh po projetí lyží na původní teplotu před projetím. Pouze v druhé jízdě druhým způsobem byl záznam sekvencí termogramů tak neostrý, že nebylo možné dostatečně přesně lokalizovat body pro měření a provést výpočet.

Tab.2: Teploty sněhu před a po projetí lyží, rozdíly těchto teplot, rychlosti pohybu lyží a doba, za kterou se ochladí sníh po projetí lyží na původní teplotu před projetím lyží.

\begin{tabular}{|c|c|c|c|c|c|c|c|c|c|}
\hline \multirow{3}{*}{ Způsob jízdy } & \multicolumn{4}{|c|}{ Teplota sněhu $\left({ }^{\circ} \mathrm{C}\right)$} & \multirow{2}{*}{\multicolumn{2}{|c|}{ Rozdíl teplot $\left({ }^{\circ} \mathrm{C}\right)$}} & \multirow{3}{*}{$\begin{array}{c}\text { Rychlost } \\
\text { lyží } \\
(\mathrm{m} / \mathrm{s})\end{array}$} & \multirow{2}{*}{\multicolumn{2}{|c|}{$\begin{array}{c}\text { Doba dosažení } \\
\text { původní teploty (s) }\end{array}$}} \\
\hline & \multicolumn{2}{|c|}{ Pravá stopa } & \multicolumn{2}{|c|}{ Levá stopa } & & & & & \\
\hline & Před & Po & Před & Po & Pravá & Levá & & Pravá & Levá \\
\hline \multirow{2}{*}{1} & $-2,7$ & $-2,3$ & $-2,2$ & $-1,9$ & 0,4 & 0,3 & 1,98 & 10,89 & 12,63 \\
\hline & $-2,7$ & $-2,2$ & $-2,2$ & $-1,7$ & 0,5 & 0,5 & 1,92 & 7,33 & 4,97 \\
\hline \multirow{2}{*}{2} & $-2,7$ & $-2,3$ & $-2,2$ & $-0,5$ & 0,4 & 1,7 & 2,98 & 10,91 & 0,72 \\
\hline & - & - & - & - & - & - & - & - & - \\
\hline \multirow{2}{*}{3} & $-2,5$ & $-2,0$ & $-2,4$ & $-1,3$ & 0,5 & 1,1 & 2,29 & 6,12 & 17,51 \\
\hline & $-2,6$ & $-2,2$ & $-2,2$ & $-1,5$ & 0,4 & 0,7 & 2,29 & 3,96 & 5,71 \\
\hline \multirow{2}{*}{4} & $-2,6$ & $-2,1$ & $-2,0$ & $-0,6$ & 0,5 & 1,4 & 2,98 & 2,96 & 8,84 \\
\hline & $-2,2$ & $-1,7$ & $-1,9$ & $-0,7$ & 0,5 & 1,2 & 3,14 & 3,67 & 7,82 \\
\hline \multirow{2}{*}{5} & $-2,0$ & $-1,4$ & $-1,6$ & $-0,4$ & 0,6 & 1,2 & 1,98 & 1,43 & 1,58 \\
\hline & $-2,1$ & $-1,5$ & $-1,7$ & $-0,3$ & 0,6 & 1,4 & 2,59 & 3,42 & 4,99 \\
\hline \multirow{2}{*}{6} & $-2,0$ & $-0,9$ & $-1,7$ & $-0,6$ & 1,1 & 1,1 & 3,37 & 35,31 & 35,80 \\
\hline & $-2,2$ & $-1,6$ & $-1,6$ & $-0,2$ & 0,6 & 1,4 & 3,14 & 1,43 & 3,07 \\
\hline Minimum & $-2,6$ & $-2,3$ & $-2,4$ & $-1,9$ & 0,4 & 0,3 & 1,92 & 1,43 & 0,72 \\
\hline Maximum & $-2,0$ & $-0,9$ & $-1,6$ & $-0,2$ & 1,1 & 1,7 & 3,37 & 35,31 & 35,80 \\
\hline Průměr & $-2,38$ & $-1,80$ & $-1,98$ & $-0,91$ & 0,58 & 1,08 & 2,612 & 9,552 & 10,782 \\
\hline SD & 0,28 & 0,49 & 0,30 & 0,63 & 0,23 & 0,46 & 0,551 & 11,409 & 11,611 \\
\hline
\end{tabular}

Vysvětlivky: Každému způsobu projetí (1-6) náleží dva řádky výsledků, protože vždy byla stopa projeta dvakrát. Jednotlivé způsoby jízdy jsou popsány výše v metodice. SD - směrodatná odchylka.

Jasná a přehledná prezentace teplot sněhu před a po projetí lyží je v krabicových grafech (Graf č.1). Je v něm vidět jejich zcela zřetelný rozdíl. Výsledek Wilcoxonova testu dokládá statisticky významný nárůst teplot $(\mathrm{p}=0,000040)$.

Největšího zahřátí sněhu a nejdelší doby návratu k původní teplotě bylo dosaženo při rychlejším projetí stop s namazanými lyžemi. Nejmenší zahřátí sněhu je pozorováno při pomalejším projetí lyžemi bez mazání. 
Graf 1: Základní statistická charakteristika teplot sněhu před a po projetí lyže.

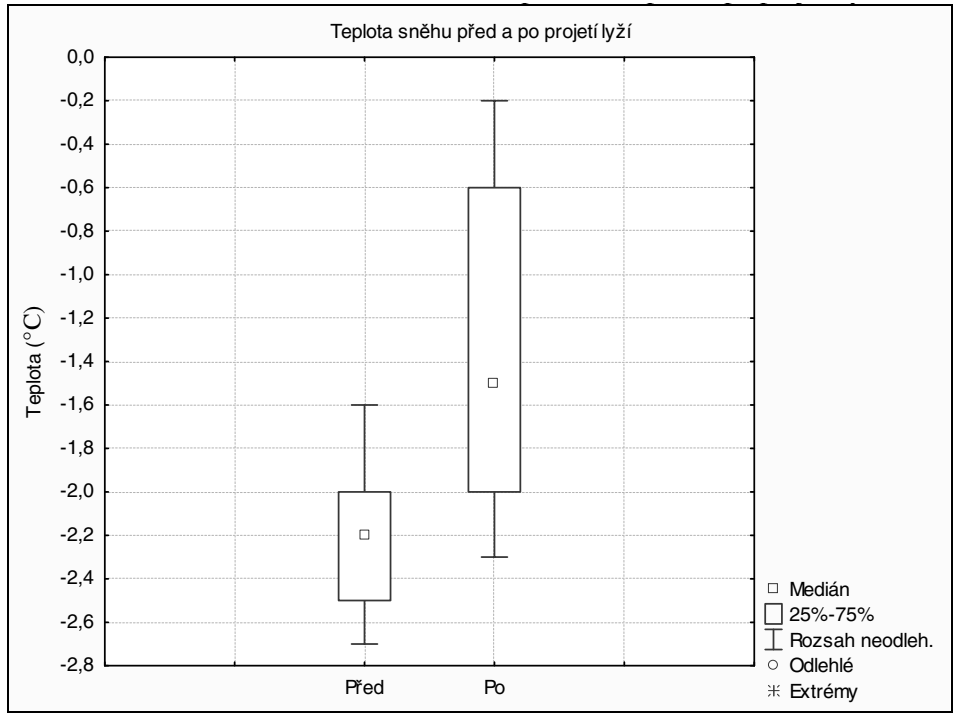

\section{DISKUSE}

Rozdílný vliv pravé a levé lyže na teplotu sněhu vidíme názorně v grafu č. 2. Na první pohled je zvýšení teploty výraznější na levé straně. To, že tento rozdíl není statisticky významný, je zřejmě způsobeno vysokou odlehlou hodnotou na pravé straně. Pro zřetelnou převahu zvýšení teploty v levé stopě proti pravé stopě připadají v úvahu dvě vysvětlení: Při průjezdu běžce těsně kolem kamery běžec přenášel svoji váhu více na levou lyži z obavy, aby nenarazil do kamery, která byla velmi blízko jeho dráhy z pravé strany. Druhým důvodem by mohla být větší vrstva použitého stoupacího vosku na skluznici, protože v př́padě voskování obou lyží byla levá lyže mazána podruhé.

Graf 2: Základní statistická charakteristika rozdílů teplot sněhu před a po projetí pravé a levé lyže.

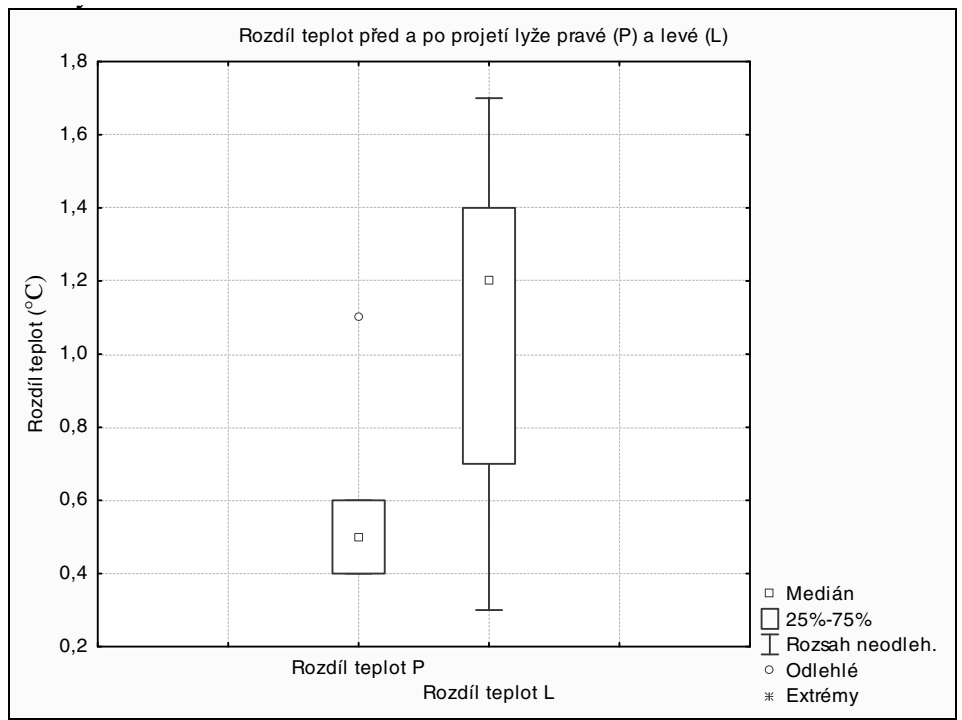

K diskusi v otázce vlivu mazání skluznice a rychlosti lyže předkládáme také graf č. 3, který představuje průměry teplotních rozdílů při různých způsobech projetí stopy. Dobře ilustruje náznak výraznějšího zvýšení teploty na levé straně a částečně také při použití vosku. 
Graf 3: Průměry rozdílů teplot sněhu před a po projetí běžce šesti různými způsoby.

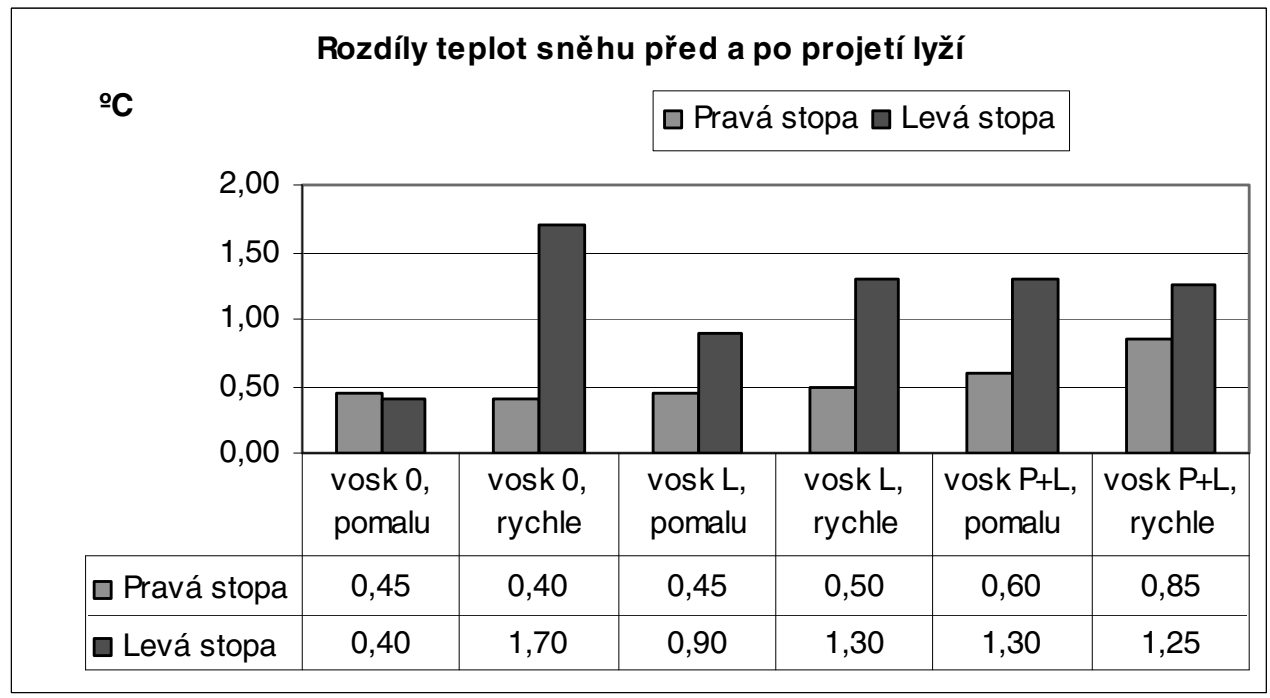

Vysvětlivky: vosk $\mathrm{O}$ - bez mazání lyže voskem, vosk $\mathrm{L}$ - po mazání levé lyže, vosk $\mathrm{P}$ - po mazání pravé lyže, vosk $\mathrm{P}+\mathrm{L}$ - po mazání prvé i levé lyže.

Zajímavá je také otázka př́ípadného vlivu rychlosti lyže na ohřátí sněhu. Tento vztah nám přibližuje graf č. 4. Závislost rozdílů teplot (před a po projetí lyže) na rychlosti lyže byla $v$ prŕípadě pravé stopy statisticky nevýznamná $(\mathrm{r}=0,4772 ; \mathrm{p}=0,1377)$ a u levé stopy významná $(\mathrm{r}=0,6657 ; \mathrm{p}=0,0254)$. Tento výsledek se velice podobá zjištěnému růstu koeficientu tření při narůstající rychlosti pohybu brusle na ledě (de Koning et al. 1992).

Graf 4: Lineární korelace rozdílu teplot sněhu (pravé a levé stopy) a rychlosti lyže

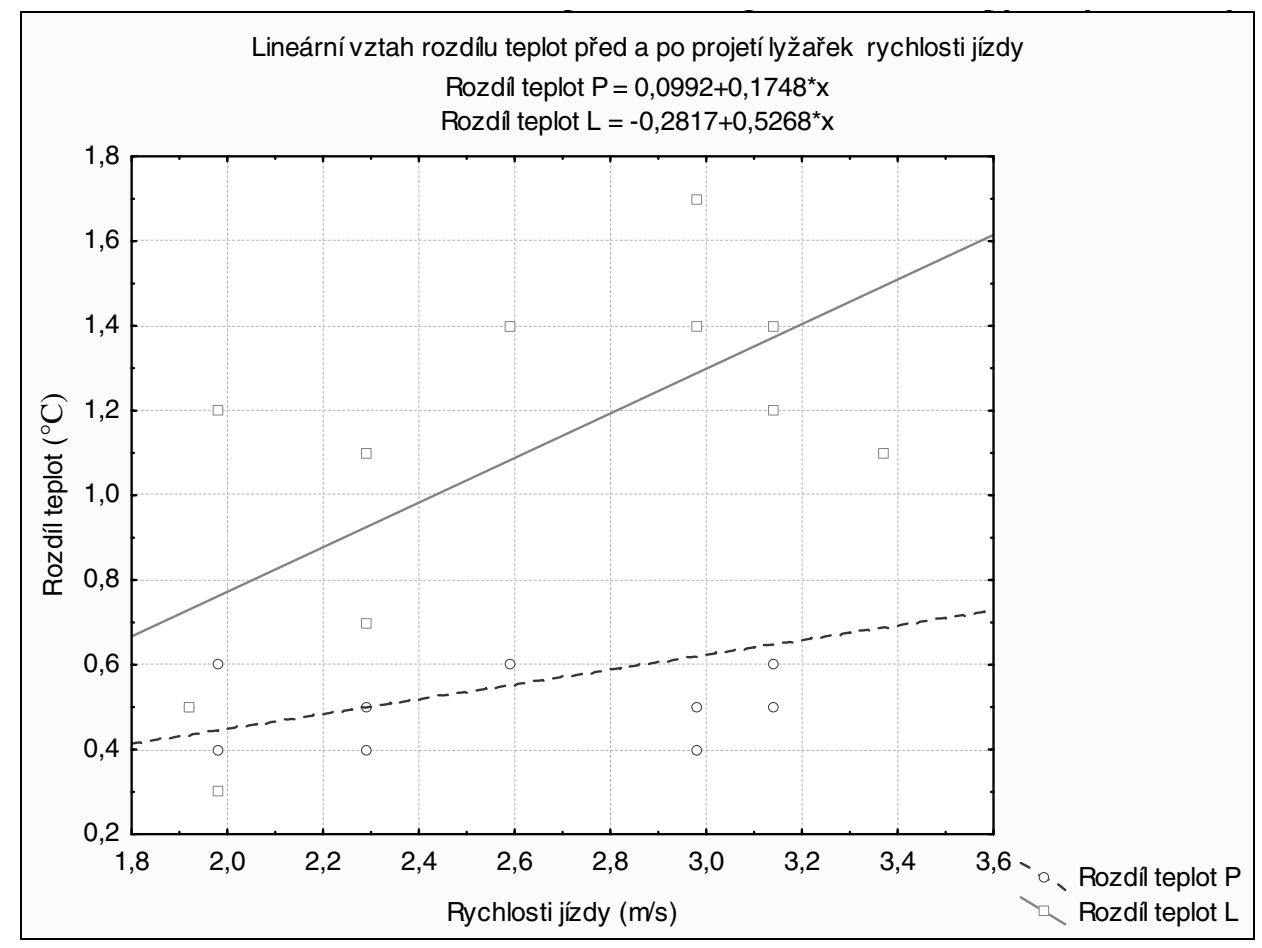


Námi zjištěné zvýšení teploty sněhu po průjezdu běžce o 0,2 až $1,7^{\circ} \mathrm{C}$ je zřejmě výrazně větší než tomu bylo ve studii o sjezdových lyžích, ve které Roberts (1991) píše o zvýšení teploty do $1,0^{\circ} \mathrm{C}$, přibližně kolem $0,3^{\circ} \mathrm{C}$.

Dynamická infračervená termografie by mohla být významným nástrojem pro sledování krátkodobých změn na povrchu sněhu. Mohla by doplnit morfologické diagnostické metody, např. rentgenovou počítačovou tomografii, které zachycují mikroskopické změny strukturální (Theile et al. 2009).

Doba, za kterou se sníh po projetí lyže opět ochladí na původní teplotu, je značně variabilní díky dvěma extrémním hodnotám přes $35 \mathrm{~s}$ (Tab. č. 2). Bylo to bezprostředně po čerstvém namazání lyží voskem bez řádného rozetření a zamrznutí. Domníváme se, že se vosk mohl částečně uvolnit $\mathrm{z}$ lyží a vytvořit izolační vrstvičku na povrchu sněhu.

V naší studii s rekreačním běžcem jsme zdaleka nedosahovali rychlostí, jaké byly zaznamenány při vrcholných soutěžích běžeckého lyžování klasickým způsobem či bruslením - 6 až 7,5 $\mathrm{m} / \mathrm{s}$ (Soumar a Bolek 2001). Při těchto rychlostech lze očekávat výraznější ohřátí sněhu třením lyže i delší dobu návratu teploty $\mathrm{k}$ hodnotám před projetím.

\section{ZÁVĚRY}

Teplota sněhu se po projetí běžce na lyžích zcela zřetelně, statisticky významně, zvyšuje (o 0,2 až $1,7^{\circ} \mathrm{C}$ ), roste s rychlostí lyže a je vyšší při větším zatížení. Prokázali jsme, že sekvenční termografie je schopna zjistit krátkodobé termodynamické změny sněhu skutečně bezprostředně před a po projetí lyže (do 0,033 s). Výhodou dynamické termovize je možnost podrobně analyzovat průběh rychlého ochlazování sněhu po projetí lyží. Nezanedbatelná je možnost výpočtu rychlosti pohybu lyže v okamžiku termografické analýzy.

Výsledky této pilotní studie podporují myšlenku následného řízeného experimentu s větším počtem měření, který by mohl přinést odpovědi na vyslovené otázky a lépe prověřit možnosti přínosu infračervené termografie $\mathrm{v}$ přípravě běžců na lyžích $\mathrm{k}$ soutěži.

Při dalším výzkumu je potřeba dbát na označení patek lyží zřetelnými značkami, kontrastními v infračervené termografii. Pro lepší stabilitu měřených bodů je vhodné použít ke kameře stativ. Měření je potřeba provádět ve stínu nebo alespoň se sluncem za kamerou, nemělo by sněžit nebo pršet. Je nutné zaznamenávat meteorologické podmínky, jejichž parametry ovlivňují výsledky analýzy získaných údajů.

\section{Literatura}

BOWDEN, F.P.; HUGHES, T.P. The mechanism of sliding on ice and snow. Proc. R. Soc. Lond. Math. Phys. Sci. 1939, 172 A, pp. 280-298. (In: Theile T.,Szabo D., Luthi A, Rhyner H., Schneebeli M. Mechanics of the Ski-Snow Contact. Tribol Lett, 2009, 36, pp. 223-231.)

BRADLEY, J.L. The sports science of curling: A practical review. Journal of Sports Science and Medicine, 2009, 8, pp. 495-500.

GNAD, T .; PSOTOVÁ, D. Běh na lyžích. Karolinum, Praha, 2005, 151 s.

HONNER, M. Infračervená kvantivativní termografie ve výzkumu fyzikálních technologií. Habilitační práce. Západočeská univerzita, Plzeň, 2004, 166 s.

de KONING, J.J.; de GROOT, G; van INGEN SCHENAU, G.J. Ice friction during speed skating. Journal of Biomechanics, 25, 8, 1992, pp. 565-571.

de KONING, J.J.; van INGEN SCHENAU, G.J. Performance-determining factors in speed skating. Biomechanics in sport. V.M.Zatsiorsky, ed., Oxford, Blackwell Science, 2000, 232-246. (In: Zatsiorsky, V.M. Kinetics of Human Motion. Human Kinetics, Champaign, 2002, pp. 86-88.)

NOVOTNÝ, J. Infračervená termografie ve sportovní medicíně. Studia Sportiva, 2009, 3, 1, s. 33-42.

SMITH, G.A. Cross-country skiing: Technique, equipment and enviromental factors affecting performance. Biomechanics in sport. V.M.Zatsiorsky, ed., Oxford, Blackwell Science, 2000, 247-270. (In: Zatsiorsky, V.M. Kinetics of Human Motion. Human Kinetics, Champaign, 2002, pp. 86-88.) 
ROBERTS, Ch.C. Infrared thermographic analysis of snow ski tracks. Proc. SPIE ssVol. 1467, 1991: pp. 207-218, Thermosense XIII, George S. Baird; Ed. Dostupné na internetu: < http://www.robertsski.com/ webpgss/skitrk.htm; 16.2.2010>

SOUMAR, L.; BOLEK, E. Běh na lyžích, Grada Publishing, Praha, 2001, 130 s.

SVENSSON, E. Ski Skating With Champions, How to Ski With Least Energy. Dynagraphics, Portland, 1994, 272 pp.

THEILE, T.; SZABO, D.; LUTHI, A.; RHYNER, H.; SCHNEEBELI, M. Mechanics of the Ski-Snow Contact. Tribol Lett, 2009, 36, pp. 223-231. 